\title{
Efforts to improve coupled in situ chemical oxidation with bioremediation: a review of optimization strategies
}

\author{
Nora B. Sutton • J. Tim C. Grotenhuis • \\ Alette A. M. Langenhoff • Huub H. M. Rijnaarts
}

Received: 7 June 2010 / Accepted: 6 July 2010 /Published online: 10 August 2010

(C) The Author(s) 2010. This article is published with open access at Springerlink.com

\begin{abstract}
Purpose In order to provide highly effective yet relatively inexpensive strategies for the remediation of recalcitrant organic contaminants, research has focused on in situ treatment technologies. Recent investigation has shown that coupling two common treatments - in situ chemical oxidation (ISCO) and in situ bioremediation-is not only feasible but in many cases provides more efficient and extensive cleanup of contaminated subsurfaces. However, the combination of aggressive chemical oxidants with delicate microbial activity requires a thorough understanding of the impact of each step on soil geochemistry, biota, and contaminant dynamics. In an attempt to optimize coupled chemical and biological remediation, investigations have focused on elucidating parameters that are necessary to successful treatment. In the case of ISCO, the impacts of chemical oxidant type and quantity on bacterial populations and contaminant biodegradability have been considered. Similarly, biostimulation, that is, the adjustment of redox conditions and amendment with electron donors, acceptors, and nutrients, and bioaugmentation have been used to expedite the regeneration of biodegradation following oxidation. The purpose of this review is to integrate recent
\end{abstract}

Responsible editor: Ji-Zheng He

N. B. Sutton $(\varangle) \cdot$ J. T. C. Grotenhuis · H. H. M. Rijnaarts

Department of Environmental Technology,

Wageningen University,

Bomenweg 2,

6703 HD Wageningen, The Netherlands

e-mail: Nora.Sutton@wur.nl

A. A. M. Langenhoff

Department of Subsurface and Groundwater,

Deltares, Princetonlaan 6,

3508 AL Utrecht, The Netherlands results on coupled ISCO and bioremediation with the goal of identifying parameters necessary to an optimized biphasic treatment and areas that require additional focus. Conclusions and recommendations Although a biphasic treatment consisting of ISCO and bioremediation is a feasible in situ remediation technology, a thorough understanding of the impact of chemical oxidation on subsequent microbial activity is required. Such an understanding is essential as coupled chemical and biological remediation technologies are further optimized.

Keywords Bioremediation - Biostimulation - Contaminant remediation · In situ chemical oxidation · Subsurface contamination

\section{Introduction}

Subsurface and groundwater contamination of recalcitrant organic compounds has created a large industry for technologies able to clean up polluted sites. The international market for the remediation sector is valued at US \$50-60 billion (Singh 2009). Conventional technologies focus on ex situ or on-site removal of contaminants through excavation or by so-called pump-and-treat remediation of groundwater. However, the high costs and health risks associated with removal of contaminated material have spurred a shift toward in situ technologies, where decomposition of xenobiotic compounds via chemical or biological pathways is contained within the subsurface environment (EPA 1998). Of the pool of remediation strategies, in situ bioremediation and, more recently, in situ chemical oxidation (ISCO) are arguably the most commonly used in situ treatments, adaptable to a variety of subsurface conditions and contaminant types. 
During an ISCO treatment, chemical oxidants are pumped into the subsurface to oxidize organic pollutants. This aggressive treatment removes source zone contaminants either sorbed to soil organic matter or pure product present as nonaqueous phase liquids (Seol et al. 2003; Watts and Teel 2005). Typical treatments include Fenton's reagent with hydrogen peroxide and ferrous iron, the less acidic modified Fenton's reagent, permanganate, persulfate, and ozone injection (Table 1). A number of review articles provide insight into the chemistry and proper application of oxidation regimens (Gates and Siegrist 1995; Kubal et al. 2008; Rivas 2006; Seol et al. 2003; Tsai et al. 2008; Watts and Teel 2005). ISCO has been successfully used to oxidize and thus lower the concentration of petroleum-derived hydrocarbons (total petroleum hydrocarbons, TPH, Crimi and Taylor 2007; Gates and Siegrist 1995; Huang et al. 2005; Jung et al. 2005; Lee and Kim 2002), polyaromatic hydrocarbons (PAH; Lee and Hosomi 2001; Masten and Davies 1997; Nam et al. 2001; Watts et al. 2002), and chlorinated hydrocarbons (Huang et al. 1999, 2005; Hunkeler et al. 2003; Northup and Cassidy 2008; Ormad et al. 1994; Schnarr et al. 1998; Siegrist et al. 1999; Vella and Veronda 1993; Watts et al. 1990). ISCO is a versatile remediation strategy, providing rapid and extensive removal of both light and dense recalcitrant compounds in pure phase.

Biological-based remediation technologies require longer time spans than chemical oxidation techniques and are more appropriate for the bioavailable plume section of a contaminated site (Singh 2009). Whereas fungi and plants alike can mediate removal of recalcitrant compounds, here we focus on biodegradation by bacterial populations. The ubiquity of hydrocarbon-utilizing bacteria indicates that natural attenuation, that is, the inherent biodegrading ability of contaminated soils, will, in most cases, occur without intervention (Surridge et al. 2009). That said, a number of technologies aim to increase the rate of bioremediation, either by increasing the bioavailability of contaminants through the application of surfactants (Menendez-Vega et al. 2007; Tsai et al. 2009c; Volkering et al. 1998) or by creating conditions ideal for general microbial growth and for specific reactivity to a compound. In the case of petroleum-based hydrocarbons, these include biostimulation with nutrients (Gallego et al. 2001; Menendez-Vega et al. 2007) and electron acceptor addition, for example, by bioventing to provide oxygen to accelerate aerobic degradation pathways (Hoeppel et al. 1991; Malina and Grotenhuis 2000). Microbial dechlorination of highly chlorinated compounds occurs under anaerobic conditions. Thus, stimulation includes the addition of an appropriate electron donor and nutrients to create ideal (redox) conditions (Aulenta et al. 2006; Hoelen et al. 2006; Song et al. 2002). Bioaugmentation with a bacterial enrichment or culture able to break down the contaminant of interest has been used to improve bioremediation of (chlorinated) hydrocarbon contaminants (Demque et al. 1997; Pu and Cutright 2007; Salanitro et al. 2000; Smith et al. 2005; Straube et al. 2003). This strategy is most commonly used to accelerate conversion of tetrachloroethene (PCE) to harmless ethene through the addition of cultures enriched with Dehalococcoides spp., the only bacterial group known to perform the complete chain of metabolic halorespiration reactions to produce ethene (Adamson et al. 2003; Hood et al. 2008; Krumins et al. 2009; Major et al. 2002; Scheutz et al. 2008; Tas et al. 2009).

Conventional wisdom dictates that chemical oxidation is not compatible with biological-based remediation techniques. The oxidative stress, increase or decrease in $\mathrm{pH}$ (persulfate and Fenton's reagent, respectively), and change in redox conditions caused by ISCO treatments significantly alter subsurface conditions and are toxic to microbial populations (Buyuksonmez et al. 1998; Macbeth et al. 2007; Miller et al. 1996). However, recent work indicates that, although chemical oxidation can temporarily reduce microbial activity, bacterial populations do regenerate contaminant degradation ability both in the field (Jones et al. 2009; Koch et al. 2007; Ladaa et al. 2008; Luhrs et al. 2006; Macbeth et al. 2005; Studer et al. 2009) and in laboratory experiments (Aunola et al. 2006; Hood et al. 2006; Kao and Wu 2000; Kulik et al. 2006; Ndjou'ou et al. 2006). In many cases, it has been concluded that ISCO pretreatment appears to improve overall remediation by (1) decreasing the concentration of pollutants to levels less toxic for the soil biota (Chapelle et al. 2005), (2) improving bioavailability of the parent compound (Kulik et al. 2006; Miller et al. 1996), (3) producing bioavailable and biodegradable oxidized daughter compounds (Lee and Hosomi 2001; Marley et al. 2003; Miller et al. 1996; Nam et al. 2001), or (4) providing oxygen for aerobic biological transformation of contaminants (Kulik et al. 2006). It has recently been suggested that, as ISCO treatment is not able to access and oxidize all residual contaminants, biological polishing is required to fully remediate a site (Cassidy et al. 2009).

This statement reflects the new direction of coupled chemical and biological treatment. Previous reviews echoed the "wait and see" mentality common to earlier experiments, where, following chemical oxidation, the regeneration of biomass was merely monitored without stimulation (Sahl and Munakata-Marr 2006; Waddell and Mayer 2003). However, in the open system encountered in situ, even local sterilization with chemical oxidants will eventually be reversed as groundwater upstream will always transport indigenous microorganisms (Brown et al. 2009). This acceptance of microbial resilience is reflected in a recent shift in the literature toward more studies investigating which parameters are essential to a biphasic remediation 
strategy and how these parameters can be manipulated. Here, we first consider the ISCO step, summarizing work in which aspects of chemical oxidation are tested for their influence on biodegradation and thus the overall remediation process. Secondly, we will review literature in which parameters essential to the rebound of an actively bioremediating microbial population are examined.

\section{Improving ISCO treatment to enhance bioremediation}

Conditions created during ISCO can significantly influence the effectiveness and efficiency of subsequent biodegradation of residual contaminants. As summarized in Table 1, chemical oxidation can create adverse environments in terms of $\mathrm{pH}$ and oxidation potential that inhibit general microbial growth and function. Recent work has indicated that the type (Cassidy et al. 2009; Kulik et al. 2006; Xie and Barcelona 2003) and quantity (Buyuksonmez et al. 1999; Jung et al. 2005; Palmroth et al. 2006a; Sahl et al. 2007; Valderrama et al. 2009) of chemical treatment have repercussions on soil geochemistry and bacterial populations and thus on the success of continued bioremediation. Additionally, the ISCO step oxidizes a specific fraction of the contamination, producing a range of oxidized substrates. The variety of compounds remaining after chemical oxidation must be bioavailable and biodegradable in order to ensure an effective bioremediation step.

\subsection{Impact of chemical oxidant type on subsequent bioremediation}

It has been shown that known ISCO treatments are versatile, able to oxidize a wide variety of substrates. Thus, rather than choosing chemical oxidation regimens based primarily on the contaminant type, treatments can be designed that cater to the requirements of the microbial population. This strategy generally improves the overall removal efficiency.

For example, the high sulfate concentrations that remain following persulfate oxidation can stimulate sulfatereducing bacteria. To avoid the evolution of the toxic $\mathrm{H}_{2} \mathrm{~S}$, Cassidy and Hampton (2009) investigated the potential of activating persulfate with calcium peroxide at alkaline pHs, which favor production of the dissolved hydrosulfide ion ( $\mathrm{HS}^{-}$). This strategy not only reduced $\mathrm{H}_{2} \mathrm{~S}$ production but also minimized the presence of toxic mercury ions through precipitation of stable mercury sulfide.

Studies have been performed to screen various oxidants to determine their impact on biological activity. Treatments of permanganate, modified Fenton's reagent, a calcium peroxide-based product, and ferric iron-activated persulfate were used to oxidize tetrachloroethylene- and ethylbenzenespiked samples (Bou-Nasr and Hampton 2006). From overall contaminant removal and cell number, it was concluded that calcium peroxide resulted in the largest mass removal of the two contaminants, $96 \%$ and $95 \%$, respectively, and an order of magnitude increase in the number of culturable heterotrophic microbes.

However, in most cases, the ISCO treatment providing the highest mass removal shows the largest negative impact on microbial activity and thus on the overall remediation efficiency (Fig. 1). Cassidy et al. (2009) tested the feasibility of coupling pre-oxidation by ozone, modified Fenton's reagent, or sodium persulfate with bioremediation of soil contaminated with 2,4-dinitrotoluene (2,4-DNT). It was determined that, although sodium persulfate less

Table 1 Conditions and reactions associated with common ISCO treatments (ITRC 2005; Teel et al. 2009; Tsitonaki et al. 2010)

\begin{tabular}{|c|c|c|c|c|}
\hline ISCO treatment & Important reactions & Optimal pH & Oxidation potential (V) & Type of injection \\
\hline Fenton's reagent and & $\mathrm{H}_{2} \mathrm{O}_{2}+\mathrm{Fe}^{2+} \rightarrow \mathrm{OH} \cdot \mathrm{OH}^{-}+\mathrm{Fe}^{3+}$ & $3-4$ & 2.8 & Liquid \\
\hline Modified Fenton's reagent & $\begin{array}{l}\mathrm{H}_{2} \mathrm{O}_{2}+\mathrm{OH} \cdot \rightarrow \mathrm{HO}_{2} \cdot+\mathrm{H}_{2} \mathrm{O} \\
\mathrm{HO}_{2} \cdot \rightarrow \mathrm{O}_{2}^{-} \cdot+\mathrm{H}^{+} \\
2 \mathrm{H}_{2} \mathrm{O}_{2} \rightarrow 2 \mathrm{H}_{2} \mathrm{O}+\mathrm{O}_{2}\end{array}$ & Neutral & $\begin{array}{l}\text { Hydroxyl radical } \\
\left(\mathrm{OH}^{-} \cdot\right)\end{array}$ & Liquid \\
\hline \multicolumn{5}{|l|}{ Activated persulfate } \\
\hline $\begin{array}{l}\text { Metal activated } \\
\text { Heat activated } \\
\text { Alkaline activated }\end{array}$ & $\begin{array}{l}\mathrm{M}^{\mathrm{n}+}+\mathrm{S}_{2} \mathrm{O}_{8}{ }^{2-} \rightarrow \mathrm{SO}_{4}^{-} \cdot+\mathrm{SO}_{4}{ }^{2-}+\mathrm{M}^{\mathrm{n}+1} \\
\mathrm{~S}_{2} \mathrm{O}_{8}{ }^{2-}+\text { heat } \rightarrow 2 \mathrm{SO}_{4}^{-} \cdot \\
\text { Reaction unknown }\end{array}$ & $\begin{array}{l}3-4 \\
\text { Neutral } \\
>10.5\end{array}$ & $\begin{array}{l}2.6 \\
\text { Sulfate radical } \\
\left(\mathrm{SO}_{4}^{-} \cdot\right)\end{array}$ & Solution \\
\hline Ozone & $\mathrm{O}_{3}+\mathrm{OH}^{-} \rightarrow \mathrm{O}_{2}+2 \mathrm{OH}^{\cdot}$ & Neutral & 2.1 & Gas \\
\hline Permanganate & $\begin{array}{l}\mathrm{MnO}_{4}^{-}+2 \mathrm{H}_{2} \mathrm{O}+3 e^{-} \rightarrow \mathrm{MnO}_{2}(\mathrm{~s})+4 \mathrm{OH}^{-} \\
2 \mathrm{KMnO}_{4}+\mathrm{C}_{2} \mathrm{HCl}_{3} \rightarrow 2 \mathrm{CO}_{2}+2 \mathrm{MnO}_{2}(\mathrm{~s}) \\
\quad+3 \mathrm{Cl}^{-}+\mathrm{H}^{+}+2 \mathrm{~K}^{+}\end{array}$ & Neutral & 1.7 & Solution \\
\hline
\end{tabular}


effectively oxidized 2,4-DNT, overall remediation occurred within 14 days, as compared to 30-90 days for modified Fenton's reagent and ozone, respectively. This result was explained by the fact that pre-oxidation with persulfate showed a minimal impact on the 2,4-DNT-degrading portion of the microbial population, both in terms of number of degraders and the time required for bacterial degradation to rebound. In experiments where permanganate, Fenton's reagent, or an oxygen-release compound containing $\mathrm{MgO}_{2}$ were paired with bioremediation on jet fuel contaminated soil, similar results were found (Xie and Barcelona 2003). Permanganate was the oxidant that showed the highest mass reduction, but did not provide the greatest overall remediation efficiency. Rather, by using the less aggressive oxygen-release compound, minimal disruption of microbial activity was observed, allowing for overall removal of up to $80 \%$ of the oil-derived hydrocarbons.

The interaction between various soil matrices, a number of ISCO treatments, and subsequent bioremediation has also been investigated (Kulik et al. 2006). Sand and peat samples spiked with creosote were treated with ozone and hydrogen peroxide, with and without the addition of ferrous iron. Whereas pre-oxidation steps showed an overall greater efficiency in organic-poor sand samples, biodegradation of PAH contaminants was greater in peat experiments, especially when ferrous iron was added to the ISCO treatment. It was concluded that traditional Fenton's reagent was the most effective pre-oxidation step for PAH-spiked sand, whereas ozone was more effective in the case of peat samples. Although it is known that the efficiency of chemical oxidation is related to the matrix, this work indicates that soil type to some extent dictates the effectiveness of coupled chemical and biological treatment.

\subsection{Optimizing the quantity of chemical oxidant}

Just as the type of chemical oxidant impacts bioremediation to varying degrees, the quantity and concentration of ISCO compounds also influence subsequent biological degradation of recalcitrant contaminants. Similar to the aforementioned section addressing the type of chemical oxidants, investigations into the impact of the amount of oxidants on bioremediation found that less aggressive mass removal in the chemical phase allowed for overall more efficient remediation (see Fig. 1). In the case of column experiments on diesel-containing soil that was ozonated at $30 \mathrm{mg} / \mathrm{L}$ for time intervals between 60 and $900 \mathrm{~min}$, the extent of biodegradation was found to be inversely proportional to the ozonation time (Jung et al. 2005). Whereas the highest chemical TPH removal was $50 \%$ for 900 min of ozonation, no further biodegradation occurred upon incubation for 9 weeks. However, the 180 -min treatment oxidized initially only $37 \%$ of TPH but ultimately removed more contamination as a coupled treatment. Similar results were obtained when various ratios of hydrogen peroxide to iron were used to oxidize creosote in aged natural samples (Valderrama et al. 2009). It was determined that a $\mathrm{H}_{2} \mathrm{O}_{2} / \mathrm{Fe}$ ratio of $20: 1$

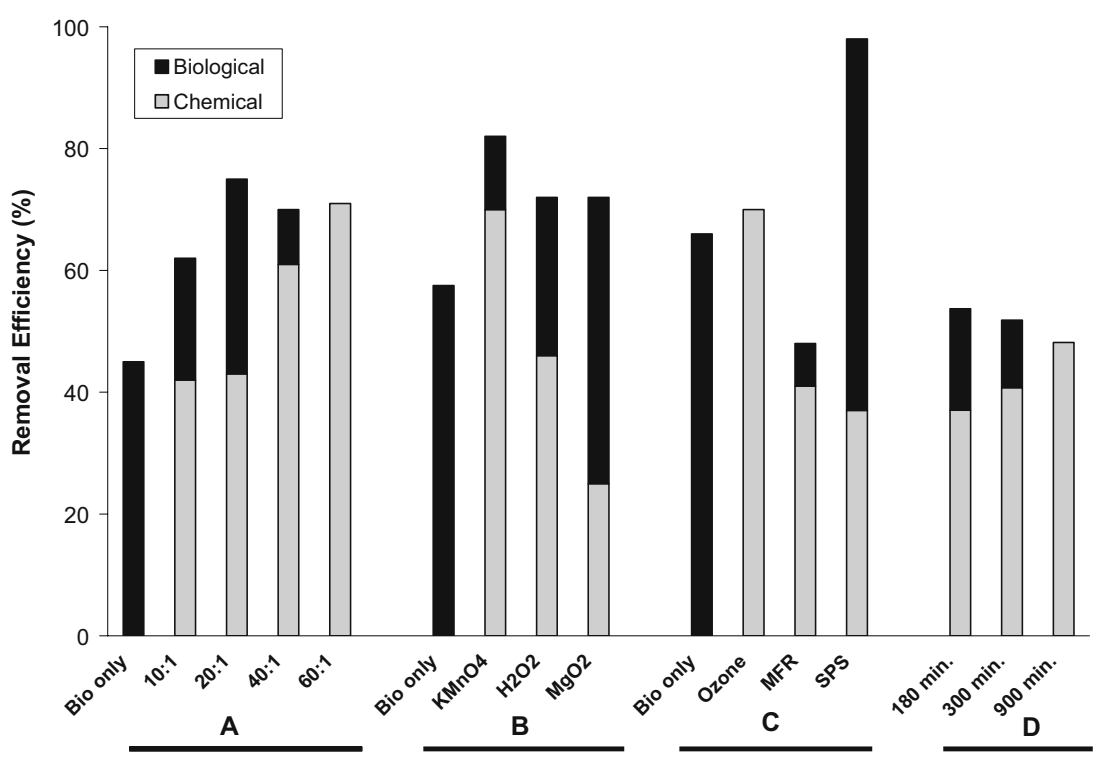

Fig. 1 Summary of removal efficiency for combined chemical and biological remediation in instances where a variety of ISCO treatments were tested. Data from A (Valderrama et al. 2009), where labels indicate the $\mathrm{H} 2 \mathrm{O} 2 / \mathrm{Fe}$ ratio used for treatment; B (Xie and Barcelona 2003), where labels indicate the type of chemical oxidant used prior to incubation for 134 days; C (Cassidy et al. 2009), where labels indicate the type of chemical oxidant, including modified Fenton's reagent and iron-activated sodium persulfate (SPS), and data are for the first 20 days of experimentation; and D (Jung et al. 2005), where labels indicate the duration of ozone treatment 
(mol/mol) was aggressive enough to remove $43 \%$ of contaminants without impeding further bioremediation, which led to a total removal of $75 \%$ of PAHs.

Column experiments, which may more accurately represent the injection of ISCO chemicals in the field, have highlighted the influence of oxidant concentration and volumetric flux on further bioremediation at a given location in the column. Working with columns containing PAH-contaminated $(3,318 \mathrm{mg} / \mathrm{kg})$, iron-rich $(16.4 \mathrm{~g} / \mathrm{kg})$ soils, Palmroth et al. (2006a) first applied a total of $0.4 \mathrm{~g}$ hydrogen peroxide per gram soil over the course of either 4 or 10 days. Subsequently, column sections were separately incubated in batch experiments to determine the potential for bioremediation. Averaging 36\% removal of $\mathrm{PAH}$, coupled treatment did not perform significantly better than control setups without chemical oxidation, in which 20 $30 \%$ of PAHs were biodegraded. However, the largest mass removal (54\%) was found in a microcosm-containing soil from the lower part of the column that received the hydrogen peroxide treatment spread over 10 days. A different study with PCE-spiked sand columns, in which the amount of permanganate and velocity of injection were adjusted, investigated the potential for coupled chemical oxidation and reductive microbial dechlorination (Sahl et al. 2007). The best results were obtained when a large quantity of oxidant with a low concentration was rapidly injected into the column- -31.5 pore volumes of $0.63 \mathrm{mM}$ $\mathrm{KMnO}_{4}$ at a rate of $120 \mathrm{~cm} /$ day. From each of these studies, it can be concluded that through minimizing the amount of direct contact that bacteria have with concentrated chemical oxidants, the biological impact of oxidation is reduced; in general, less aggressive oxidation improves the overall remediation efficiency.

\subsection{Bioavailability and biodegradability of contaminants following ISCO}

In addition to optimizing the ISCO step to reduce biological impacts, it is essential to understand the influence of chemical oxidation on the biodegradability and bioavailability of the remaining contaminant pool (Lee and Hosomi 2001; Miller et al. 1996; Nam et al. 2001). Although most ISCO treatments increase bioavailability, oxidation with permanganate can reduce bacterial access to contaminants. Upon reaction with organic compounds, precipitation of manganese oxide occurs, which reduces soil permeability (Siegrist et al. 2002) and can encapsulate contaminants present as nonaqueous phase liquids (MacKinnon and Thomson 2002). As a result, this portion of the pollutant remains inaccessible to either bacterial degradation or dissolution into the aqueous phase. In previous lab studies, increased bioremediation was associated with setups with a low concentration permanganate solution which was injected at high velocity (Sahl et al. 2007). Although regeneration of microbial activity could occur more rapidly under less oxidizing conditions, improved overall remediation efficiency may also be attributed to higher bioavailability of the remaining contaminant concentration under lower permanganate concentrations. This work reinforces the importance of considering whether post-ISCO conditions are amenable to bacterial polishing when planning a chemical oxidation strategy.

Whereas chemical oxidation can either positively or negatively impact bioavailability, ISCO generally improves biodegrability of the contaminant pool. A number of studies have investigated which parent and daughter compounds within a mix of substrates are broken down during the chemical or biological remediation steps in an effort to determine how to optimally treat the whole contamination. Some work has suggested that the readily biodegradable fraction of PAHs was chemically removed in the course of Fenton's reagent oxidation, thus impeding further bioremediation (Aunola et al. 2006). However, other research has found that pre-ozonation produced short chain daughter compounds that were more easily biodegradable (Liang et al. 2009). Similarly, Fenton's reagent treatment of spiked benz(a)anthracene samples oxidized $43 \%$ of the contamination to produce benz(a)anthracene7,12-dione (Lee and Hosomi 2001). During 63 days of incubation, $98 \%$ of the daughter compound was removed, as compared to only $12 \%$ of the parent compound, for an overall 54\% removal of benz(a)anthracene. Manipulation of the ISCO phase to optimize the removal of the less biodegradable fraction of the contaminant was not further discussed.

Work on weathered crude oil samples indicated that pretreatment with permanganate influenced the biodegradation efficiency of different components of the contamination (Wrenn et al. 2007). Biological degradation of the resin and aromatic fractions increased following permanganate treatment, while bioremediation of the aliphatic fraction was reduced by $50-60 \%$. Similarly, when optimizing Fenton's reagent dosages for subsequent bioremediation of PAH-contaminated soil, it was noted that chemical treatment parameters had an influence on the fraction of ring sizes removed (Valderrama et al. 2009). More of the less biodegradable five-ring PAHs were chemically oxidized in treatments with higher hydrogen peroxide concentrations. However, optimal oxidant ratios for five-ring $\mathrm{PAH}$ removal $\left(60: 1 \quad \mathrm{H}_{2} \mathrm{O}_{2} / \mathrm{Fe}\right)$ had a negative effect on the regeneration of the bioremediating microbial community. Thus, this study does indicate the potential for designing optimized treatment strategies in which the costs in terms of regeneration of the bacterial population are balanced with the benefits associated with removal of less biodegradable compounds. 


\section{Optimizing microbial regeneration following ISCO}

Ideally, the last moment of ISCO coincides with the first moment of bioremediation. In practice, regeneration of microbial activity is a process. Just as the microbiology, geochemistry, and residual contaminant concentrations of soil must be considered during chemical oxidation, a number of parameters can be manipulated at the beginning of bioremediation. After ISCO, the naturally occurring degradation processes inherent to the subsurface, so-called natural attenuation, have been disturbed. In the process of enhanced or stimulated natural attenuation, optimal conditions for bioremediation are recreated through the addition of electron acceptors or donors, nutrients, and bacteria (bioaugmentation). Significant work has investigated biostimulation, bioaugmentation, and natural attenuation. However, in view of the fact that chemical oxidation can have profound impacts on soil characteristics and biota, we consider here only work in which pre-oxidation occurs. Biostimulation in terms of the adjustment of redox conditions to promote either aerobic or anaerobic bioremediation (Section 3.1) and amendment with electron donors and nutrients (Section 3.2) are techniques that have been used to ensure the proper activity of biodegrading microbes. Bioaugmentation to re-inoculate soils with depleted microbial populations will also be considered. A summary of conditions set for aerobic and anaerobic bioremediation in chemically pre-oxidized soils is given in Tables 2 and 3.

\subsection{Redox process conditions in pre-oxidized soils}

Creating and maintaining aerobic or anaerobic environments for rapid removal of a particular contaminant is challenging. Aerobic conditions are generally conducive to biodegradation of petroleum-based hydrocarbons and less halogenated compounds, whereas anaerobic conditions are required for microbial mediation of highly halogenated compounds. Chemical oxidation and aerobic bioremediation can be combined relatively easily. Bioventing and aerobic flushing to encourage bioremediation of petroleumderived hydrocarbons are practices common to the current subsurface remediation market and which in research have been mimicked in the lab by maintaining oxygen saturation in column or microcosm experiments (Cassidy et al. 2009; Jung et al. 2005; Kulik et al. 2006; Palmroth et al. 2006b). Often increased biological degradation has been attributed to aerobic conditions created by chemical oxidation (Kulik et al. 2006; Palmroth et al. 2006a). Studies have shown that low concentrations of hydrogen peroxide can be used instead of air flushing to meet biological oxygen demands for oil degradation in soils pretreated with Fenton's reagent (Tsai et al. 2009b). Other work associated an increase in hydrogen peroxide concentrations, from 100 to $900 \mathrm{mg} / \mathrm{L}$, with TPH removal efficiencies improving from $47 \%$ to $69 \%$, respectively (Tsai et al. 2009a). In field applications, this has led to the development of a variety of commercially available oxygenating products that both mobilize and partially oxidize contaminants while simultaneously providing oxygen to stimulate aerobic biodegradation (Baird and Knight 2008; Blondel et al. 2007; Lessard et al. 2007; Ochs and Singh 2007).

Anaerobic in situ biodegradation of halogenated organic contaminants dissolved in groundwater by adding electron donors and nutrients has been proven and widely applied in the last decade (Aulenta et al. 2006; Hoelen et al. 2006; Song et al. 2002). However, the reduced bioavailability of pure product in the source zone and adsorption to the organic-rich fraction of the solid phase matrix impedes full bioremediation (Semple et al. 2003). For these recalcitrant source areas, chemical oxidation pretreatment followed by anaerobic bioremediation may offer a solution. In contrast to aerobic bioremediation, rapid recreation of anaerobic conditions for dehalogenation in pre-oxidized soils can be challenging. Work in the field has confirmed the rebound of anaerobic dechlorination by molecular techniques in trichloroethylene (TCE)-contaminated sites pre-oxidized with permanganate (Jones et al. 2009) and persulfate (Studer et al. 2009). The regeneration of anoxic conditions amenable to dehalogenation generally requires input of electron donors. In the field, such an increase in available electron donors has been attributed to the mobilization of soil organic matter by chemical oxidation (Westersund et al. 2006). In soils and engineered lab systems with less organic matter content, addition of carbon substrates is often required (see Table 3; Hrapovic et al. 2005; Sahl et al. 2007).

Although providing proper and ample carbon and nutrient sources is essential to microbial activity, the redox process conditions required for bioremediation must be considered when choosing an ISCO treatment. Thus, chemical oxidants, such as hydrogen peroxide, that produce molecular oxygen are better suited to the aerobic biodegradation phases. In contrast, permanganate oxidation occurs via direct electron transfer without the generation of oxygen (Wiberg and Saegebarth 1957); however, the by-product of chemical oxidation, manganese oxide, can inhibit reductive dechlorination by acting as an alternative electron acceptor (Hood et al. 2006). In spite of this, permanganate is often preferred for studies where anaerobic conditions must be regenerated (Hrapovic et al. 2005; Jones et al. 2009; Sahl et al. 2007; Tsai et al. 2009c).

Addition of carbon substrates has been used to increase the rates of both aerobic and anaerobic bioremediation pathways (see Tables 2 and 3). In batch experiments with fuel oilspiked soil, increased biodegradation was observed when microcosms were supplemented with cane molasses in the 
Table 2 Summary of investigations on the feasibility and optimal conditions for combined chemical oxidation and aerobic bioremediation

\begin{tabular}{|c|c|c|c|c|}
\hline Reference & $\begin{array}{l}\text { Contaminant type } \\
\text { and initial concentration }\end{array}$ & $\begin{array}{l}\text { ISCO treatment (length } \\
\text { of treatment) }\end{array}$ & $\begin{array}{l}\text { Conditions set for bioremediation } \\
\text { (length of incubation) }\end{array}$ & Removal efficiency \\
\hline $\begin{array}{l}\text { Cassidy et al. } \\
2009\end{array}$ & $\begin{array}{l}\text { 2.4-Dinitrotoluene } \\
11,450 \mathrm{mg} / \mathrm{kg}\end{array}$ & $\begin{array}{l}\text { Ozone }(48 \mathrm{~h}) \\
\text { Modified Fenton's reagent } \\
\text { (one treatment) } \\
\text { Iron-activated sodium } \\
\text { persulfate (one treatment) }\end{array}$ & $\begin{array}{l}\text { Aerobic incubation }(2-14 \text { weeks }) \\
\text { Amendment with } \mathrm{NH}_{4} \text { and } \mathrm{PO}_{4}\end{array}$ & $98 \%$ \\
\hline Jung et al. 2005 & $\begin{array}{l}\text { Diesel } \\
2,700 \mathrm{mg} / \mathrm{kg} \mathrm{TPH}\end{array}$ & Ozone $(3-15$ h) & Aerobic incubation ( 9 weeks) & $\begin{array}{l}>50 \% \text {, exact value not } \\
\text { reported }\end{array}$ \\
\hline Kulik et al. 2006 & $\begin{array}{l}\text { PAH } \\
1,419 \mathrm{mg} / \mathrm{kg} \\
\text { (sand samples) } \\
2,370 \mathrm{mg} / \mathrm{kg} \\
\text { (peat samples) }\end{array}$ & $\begin{array}{l}\text { Fenton's reagent }(24 \mathrm{~h}) \\
\text { Ozone }(2-5 \mathrm{~h})\end{array}$ & Aerobic incubation ( 8 weeks) & $\begin{array}{l}75-94 \% \text { (sand samples) } \\
55-75 \% \text { (peat samples) }\end{array}$ \\
\hline Liang et al. 2009 & $\begin{array}{l}\text { Crude oil } \\
28,000 \mathrm{mg} / \mathrm{kg} \\
\text { (before ozonation) }\end{array}$ & Ozone $(6 \mathrm{~h})$ & $\begin{array}{l}\text { Aerobic incubation ( } 18 \text { weeks) } \\
\text { Amendment with nutrients } \\
\text { Bioaugmentation }\end{array}$ & $\begin{array}{c}35-40 \% \text { (ozone }+ \\
\text { bioremediation) }\end{array}$ \\
\hline $\begin{array}{l}\text { Palmroth et al. } \\
\text { 2006a }\end{array}$ & $\begin{array}{l}\text { PAH } \\
3,960 \mathrm{mg} / \mathrm{kg}\end{array}$ & $\begin{array}{l}\text { Modified Fenton's reagent } \\
(4-10 \text { days })\end{array}$ & Aerobic incubation (5-16 weeks) & $36-54 \%$ \\
\hline $\begin{array}{l}\text { Palmroth et al. } \\
2006 b\end{array}$ & $\begin{array}{l}\text { PAH } \\
3,318 \mathrm{mg} / \mathrm{kg}\end{array}$ & $\begin{array}{l}\text { Modified Fenton's reagent } \\
(10 \text { days })\end{array}$ & Aerobic incubation (8-16 weeks) & $43-59 \%$ \\
\hline Tsai et al. 2009a & $\begin{array}{l}\text { Fuel oil } \\
5,000 \mathrm{mg} / \mathrm{kg} \mathrm{TPH}\end{array}$ & Fenton's reagent (one treatment) & $\begin{array}{l}\text { Aerobic incubation }(17 \text { weeks }) \\
\text { Amendment with } \mathrm{N}, \mathrm{P} \text {, and carbon } \\
\text { source }\end{array}$ & $47-75 \%$ \\
\hline Tsai et al. 2009b & $\begin{array}{l}\text { Fuel oil } \\
1,000 \mathrm{mg} / \mathrm{kg} \text { TPH } \\
5,000 \mathrm{mg} / \mathrm{kg} \text { TPH } \\
10,000 \mathrm{mg} / \mathrm{kg} \mathrm{TPH}\end{array}$ & Fenton's reagent (one treatment) & Aerobic incubation (17 weeks) & $\begin{array}{l}100 \% \text { in } 3 \text { step process with } \\
\text { flushing with surfactant, } \\
\text { ISCO, and bioremediation }\end{array}$ \\
\hline $\begin{array}{l}\text { Valderrama et al. } \\
2009\end{array}$ & $\begin{array}{l}\text { PAH } \\
1,203 \mathrm{mg} / \mathrm{kg}\end{array}$ & Fenton's reagent $(0.5$ h $)$ & $\begin{array}{l}\text { Aerobic incubation } \\
\text { (length unclear) } \\
\text { Amendment with nutrients } \\
\text { Bioaugmentation }\end{array}$ & $75 \%$ \\
\hline $\begin{array}{l}\text { Xie and Barcelona } \\
2003\end{array}$ & $\begin{array}{l}\text { Jet fuel } \\
27 \mathrm{mg} / \mathrm{L} \mathrm{TPH}\end{array}$ & $\begin{array}{l}\text { Permanganate }(25 \text { days }) \\
\text { Hydrogen peroxide }(25 \text { days }) \\
\text { Magnesium peroxide (oxygen- } \\
\text { release compound) ( } 25 \text { days })\end{array}$ & $\begin{array}{l}\text { Aerobic incubation (19 weeks) } \\
\text { Amendment with nutrients, carbon } \\
\text { source, and trace elements } \\
\text { Bioaugmentation }\end{array}$ & $\begin{array}{l}15-80 \% \text { dependent upon } \\
\text { fraction of oil }\end{array}$ \\
\hline
\end{tabular}

presence of excess oxygen (Tsai et al. 2009a). Similarly, carbon sources, such as ethanol and acetate (each $100 \mathrm{mg} / \mathrm{L}$; Hrapovic et al. 2005) and methanol (2.0 mM; Sahl et al. 2007) have been added as electron donors to increase the rate of anaerobic halorespiration. Whereas regeneration of anaerobic TCE dechlorination activity was successful in the former citation, multiple attempts by Hrapovic et al. to biostimulate with electron donors proved fruitless. As elaborated upon in Section 3.3, biological degradation of TCE did occur upon flushing with natural groundwater, indicating that electron donor sources were sufficiently present and other factors were impeding halorespiration, 
Table 3 Summary of investigations on the feasibility and optimal conditions for combined chemical oxidation and anaerobic bioremediation

\begin{tabular}{|c|c|c|c|c|}
\hline Reference & $\begin{array}{l}\text { Contaminant type } \\
\text { and initial } \\
\text { concentration }\end{array}$ & $\begin{array}{l}\text { ISCO treatment } \\
\text { (length of treatment) }\end{array}$ & $\begin{array}{l}\text { Conditions set for bioremediation } \\
\text { (length of incubation) }\end{array}$ & Removal efficiency \\
\hline $\begin{array}{l}\text { Buyuksonmez } \\
\text { et al. } 1999\end{array}$ & $\begin{array}{l}\text { Tetrachloroethene } \\
\text { 3-9 mg/L (setup } \\
\text { dependent) }\end{array}$ & $\begin{array}{l}\text { Fenton's reagent (added } \\
\text { hourly for } 5 \mathrm{~h} \text { ) }\end{array}$ & $\begin{array}{l}\text { Anaerobic incubation ( } 3 \text { days }) \\
\text { Amendment with nutrients, trace } \\
\text { elements and vitamins } \\
\text { Bioaugmentation }\end{array}$ & $17-74 \%$ \\
\hline $\begin{array}{l}\text { Hrapovic et al. } \\
2005\end{array}$ & $\begin{array}{l}\text { Trichloroethene } \\
\text { Unclear, effluent } \\
\text { concentration of } \\
\sim 500 \mathrm{mg} / \mathrm{L}\end{array}$ & $\begin{array}{l}\text { Permanganate } \\
\text { (22 days) }\end{array}$ & $\begin{array}{l}\text { Anaerobic incubation ( } 290 \text { days }) \\
\text { Amendment with nutrients and } \\
\text { carbon sources } \\
\text { Bioaugmentation } \\
\text { Addition of natural groundwater }\end{array}$ & $\begin{array}{l}\text { Overall efficiency in terms of ethene } \\
\text { production not reported } \\
\text { Limited rebound of microbial } \\
\text { dechlorination following ISCO treatment }\end{array}$ \\
\hline $\begin{array}{l}\text { Sahl et al. } \\
2007\end{array}$ & $\begin{array}{l}\text { Tetrachloroethene } \\
82-232 \mathrm{mg} / \mathrm{L} \\
\text { (column dependent) }\end{array}$ & $\begin{array}{l}\text { Permanganate } \\
\left(\begin{array}{ll}1.7-610 & \mathrm{~h}\end{array}\right)\end{array}$ & $\begin{array}{l}\text { Anaerobic incubation (unclear) } \\
\text { Amendment with nutrients, carbon } \\
\text { source, trace elements }\end{array}$ & $\begin{array}{l}\text { Overall efficiency in terms of } \\
\text { ethene production not reported } \\
\text { Degradation of PCE to cis-DCE observed }\end{array}$ \\
\hline
\end{tabular}

such as nutrient availability and the presence of a microbial population acclimated to biodegradation.

\subsection{Nutrients and biodegradation in pre-oxidized soils}

Nutrient amendment is a common approach to stimulate bacterial growth and may be necessary in lab experiments with nutrient-poor samples without natural influx of nutrient-rich groundwater. Many batch experiments with ISCO have been performed in a phosphate buffer, which simultaneously controls the $\mathrm{pH}$ and provides phosphate to microbes (Cassidy et al. 2009; Liang et al. 2009; Valderrama et al. 2009). Ammonium may be added for analytical reasons (Cassidy et al. 2009), or in conjunction with ample trace metals, minerals, and vitamins to create optimal conditions for biomass growth (Sahl et al. 2007; Xie and Barcelona 2003). In experiments in which ammonium and phosphate were either added to or absent from microcosms with fuel oil-spiked samples, TPH removal was $6-14 \%$ higher when nutrients were present (Tsai et al. 2009a).

Although excess nutrients may improve bioremediation, amendment may not always be necessary. It has been suggested that through oxidizing soil organic matter, chemical oxidants actually release nutrients (Sirguey et al. 2008; Westersund et al. 2006). Researchers investigating the impact of ISCO on subsequent plant growth found that phosphate concentrations increase in soils oxidized with either Fenton's reagent or permanganate due to oxidation and release of soil organic matter (Sirguey et al. 2008). Although ammonium concentrations increased up to 20fold upon treatment with Fenton's reagent, overall concentrations of nitrate and organic carbon decreased; such reductions in the availability of electron donors and acceptors as well as nutrients would have repercussions on biomass growth. Kulik et al. (2006) suggested that increased bioremediation in pre-oxidized peat, as compared to sand, was due to the high nutrient content in peat. Further investigation is required to understand the relationships between soil type, nutrient availability, and dynamics thereof following chemical oxidation.

\subsection{Bioaugmentation in pre-oxidized soils}

Addition of bacterial cultures or enrichments frequently occurs in laboratory experiments. This occasionally takes place prior to chemical oxidation in order to ensure proper bacterial function. Microbial populations are added after ISCO to re-inoculate lab experiments and, arguably, to simulate the processes encountered in the field. However, work investigating bioremediation in pre-oxidized soils has not yet conclusively shown the necessity of bioaugmentation. In two recent studies, experimental setups were inoculated prior to ISCO treatment with either a dechlorinating microbial culture to guarantee PCE degradation ability (Sahl et al. 2007) or a wastewater enrichment culture to ensure sufficient biomass was available (Valderrama et al. 2009). Both investigations saw successful regeneration of bioremediation activity under some of the experimental conditions tested. Other researchers investigated the influence of cell number on PCE degradation (Buyuksonmez et al. 1999). Here, a culture of Xanthobacter flavus, a hydrogen peroxide-resistant species known to degrade the major by-product of Fenton's reagent oxidation of PCE (dichloroacetic acid), was grown under oxidative stress prior to experimentation. Although results did identify 
optimal cell numbers associated with specific Fenton's reagent dosages, it would be nearly impossible to create such specific conditions in a field setting.

Enrichments of indigenous soil microorganisms have been used for re-inoculation following chemical oxidation. In lab experiments where microcosms were autoclaved prior to ISCO to ensure that all contaminant removal could be attributed to chemical oxidation, it was clear that reinoculation was required to regenerate bioremediation (Xie and Barcelona 2003). The impact of bioaugmentation has been less conclusive in other studies testing this as a variable in coupled chemical and biological remediation. In one case, microbial community dynamics with or without addition of an enriched mixed culture following ozonation of soil with an initial oil concentration of $56 \mathrm{mg} / \mathrm{g}$ were monitored on a microarray (Liang et al. 2009). Although there was slightly less residual TPH following treatment, namely $17 \mathrm{mg} / \mathrm{g}$ in the setup with added biomass versus $18 \mathrm{mg} / \mathrm{g}$ in the blank, this could not be explained by a significant difference in the amount or variety of genes measured by the microarray. In permanganate-pre-oxidized TCE-spiked samples, no dechlorination was observed following a variety of bioaugmentation steps with an inoculation of a TCE-degrading Dehalococcoides sp. and other species able to respire on hydrogen and the carbon source provided (Hrapovic et al. 2005). However, once the column was flushed with site groundwater, anaerobic conditions developed and cis-dichloroethene (DCE) was detected. Thus, it is not clear if bioremediation was initiated by (1) biostimulation with specific nutrients present in the site groundwater but not in synthetic groundwater, (2) the introduction of dehalogenating bacteria from the site, or (3) the addition of a groundwater bacterial consortium able to create anaerobic conditions necessary for the activity of cultured Dehalococcoides species. In work focused on investigating bioremediation parameters, an enrichment culture or native sediment slurry was added to all experimental setups (Lee et al. 2008; Nam et al. 2001); thus, the impact of biomass addition could not be assessed. Clearly, future work is required to judge both the necessity of and requirements for successful bioaugmentation in preoxidized soils in the lab in order to ascertain the transferability of this technique to the field.

\section{Conclusions and future directions}

Coupled ISCO and bioremediation is not only feasible but, when properly implemented, can provide more extensive, rapid, and cost-effective treatment than either chemical or biological techniques alone. Although pre-oxidation impacts microbial communities and may adversely alter redox conditions, chemical oxidation can stimulate biore- mediation through improving bioavailability and biodegradability of contaminant substrates, providing oxygen, and in some cases releasing nutrients. In order to create a balanced and optimized treatment strategy, a variety of parameters within the chemical and biological remediation phases must be considered.

ISCO regimens should be chosen and performed in a manner that minimizes microbial interaction with concentrated chemical oxidants. When a variety of chemical oxidant types, concentrations, or injection strategies were tested, heightened chemical mass removal was not associated with overall increased efficiency. This was due to the reduction in bioremediation potential from harsh chemical treatments. Chemical oxidation can also be manipulated to target the less biodegradable fraction of the contamination, leaving bioavailable oxidized by-products for microbial remediation. Future investigations should focus on further optimizing the chemical treatment to reduce microbial impact and improve the ease of substrate biodegradation. To this end, it is essential that experimentation include (1) more column setups which better recreate oxidant flow dynamics in the lab and (2) naturally aged samples with which the impact of field sorption of contaminants onto soil particles can be assessed.

Adjustment of redox conditions, electron donors, and electron acceptors; amendment with nutrients; and addition of bacterial cultures are techniques used to stimulate the regeneration of microbial activity following ISCO. Redox conditions have been manipulated (in some cases with chemical oxidants) to encourage specific aerobic or anaerobic biodegradation pathways. Conclusive evidence for the necessity and/or success of bioaugmentation remains illusive. As laboratory work with enriched cultures under optimized conditions has proven to be inconclusive, field application would obviously be even more challenging; reliance on incomplete sterilization by ISCO and a natural or geohydrologically enhanced reinoculation by groundwater flow may be more feasible strategies. Through providing an excess of electron donors and acceptors, rebound of biodegrading communities may also be encouraged.

In view of the fact that often the time required for remediation increases or that the efficiency decreases when technologies are transferred from the laboratory to the field, a full understanding and optimization of the processes essential to sequential chemical and biological treatment are required to ensure success in field applications. Future work should focus on the implications of chemical oxidation on nutrient dynamics in a given soil matrix and on the bacterial requirements for regeneration. Through concentrating on the aforementioned directions, research-based, efficient, and cost-effective biphasic treatment strategies can be designed. Once tested in the lab, 
optimized coupled ISCO and bioremediation can then be further developed as an effective remediation technology in the field.

Acknowledgments This research is funded by the European Union consortium Upsoil, a Seventh Framework Programme within Theme 6. number 226956 (www.upsoil.eu). The authors would also like to thank two anonymous reviewers for their valuable comments.

Open Access This article is distributed under the terms of the Creative Commons Attribution Noncommercial License which permits any noncommercial use, distribution, and reproduction in any medium, provided the original author(s) and source are credited.

\section{References}

Adamson DT, McDade JM, Hughes JB (2003) Inoculation of DNAPL source zone to initiate reductive dechlorination of PCE. Environ Sci Technol 37:2525-2533

Aulenta F, Majone M, Tandoi V (2006) Enhanced anaerobic bioremediation of chlorinated solvents: environmental factors influencing microbial activity and their relevance under field conditions. J Chem Technol Biotechnol 81:1463-1474

Aunola TA, Goi A, Palmroth MRT, Langwaldt JH, Tuhkanen TA (2006) Removal of PAHs from creosote oil contaminated soil by addition of concentrated $\mathrm{H}_{2} \mathrm{O}_{2}$ and biodegradation. $\mathrm{J}$ Adv Oxid Technol 9:11-19

Baird D, Knight R (2008) Novel treatment approach: in situ chemical oxidation combined with enhanced aerobic bioremediation. In: Proceedings of the sixth international conference on remediation of chlorinated and recalcitrant compounds. Battelle, Monterey, pp D-012

Blondel J, Nicolet P, Jacquet R, Michiels T (2007) Using dilute H2O2 for bioremediation of chlorinated phenols: mass balance demonstrates the results. In: Proceedings of the ninth international in situ and onsite bioremediation symposium. Battelle, Baltimore, pp D-07

Bou-Nasr J, Hampton D (2006) Comparative study of the effect of four ISCO oxidants on PCE oxidation and aerobic microbial activity. In: Proceedings of the fifth international conference on remediation of chlorinated and recalcitrant compounds. Battelle, Monterey, pp D-23

Brown RA, Lewis R, Leahy MC, Luhrs RC (2009) In there life after ISCO? The effect of oxidants on in situ bioremediation. In: Proceedings of the tenth international in situ and on-site bioremediation symposium. Battelle, Baltimore, pp K-12

Buyuksonmez F, Hess TF, Crawford RL, Watts RJ (1998) Toxic effects of modified Fenton reactions on Xanthobacter flavus FB71. Appl Environ Microbiol 64:3759-3764

Buyuksonmez F, Hess T, Crawford R, Paszczynski A, Watts R (1999) Optimization of simultaneous chemical and biological mineralization of perchloroethylene. Appl Environ Microbiol 65:2784

Cassidy D, Hampton D (2009) Hydrogen sulfide production from persulfate oxidation - implications for remediation. In: Proceedings of the tenth international in situ and on-site bioremediation symposium. Battelle, Baltimore, pp K-15

Cassidy D, Northup A, Hampton D (2009) The effect of three chemical oxidants on subsequent biodegradation of 2, 4dinitrotoluene (DNT) in batch slurry reactors. J Chem Technol Biotechnol 84:820-826

Chapelle FH, Bradley PM, Casey CC (2005) Behavior of a chlorinated ethene plume following source-area treatment with Fenton's reagent. Ground Water Monit Remediat 25:131-141
Crimi ML, Taylor J (2007) Experimental evaluation of catalyzed hydrogen peroxide and sodium persulfate for destruction of BTEX contaminants. Soil Sediment Contam 16:29-45

Demque DE, Biggar KW, Heroux JA (1997) Land treatment of diesel contaminated sand. Can Geotech J 34:421-431

EPA (1998) Field applications of in situ remediation technologies: chemical oxidation. In: Solid waste and emergency responses. EPA, Washington, DC, pp 37

Gallego JLR, Loredo J, Llamas JF, Vazquez F, Sanchez J (2001) Bioremediation of diesel-contaminated soils: evaluation of potential in situ techniques by study of bacterial degradation. Biodegradation 12:325-335

Gates DD, Siegrist RL (1995) In-situ oxidation of trichloroethylene using hydrogen-peroxide. J Environ Eng 121:639-644

Hoelen TP, Cunningham JA, Hopkins GD, Lebron CA, Reinhard M (2006) Bioremediation of cis-DCE at a sulfidogenic site by amendment with propionate. Ground Water Monit Remediat 26:82-91

Hoeppel RE, Hinchee RE, Arthur MF (1991) Bioventing soils contaminated with petroleum hydrocarbons. J Ind Microbiol 8:141-146

Hood E, MacKinnon LK, Bertrand D, Major D, Dennis P (2006) Evaluation of sequential application of chemical oxidation and bioaugmentation. In: Proceedings of the fifth international conference on remediation of chlorinated and recalcitrant compounds. Battelle, Monterey, pp D-60

Hood ED, Major DW, Quinn JW, Yoon WS, Gavaskar A, Edwards EA (2008) Demonstration of enhanced bioremediation in a TCE source area at Launch Complex 34, Cape Canaveral Air Force Station. Ground Water Monit Remediat 28:98-107

Hrapovic L, Sleep BE, Major DJ, Hood ED (2005) Laboratory study of treatment of trichloroethene by chemical oxidation followed by bioremediation. Environ Sci Technol 39:2888-2897

Huang K, Hoag G, Chheda P, Woody B, Dobbs G (1999) Kinetic study of oxidation of trichloroethylene by potassium permanganate. Environ Eng Sci 16:265-274

Huang KC, Zhao ZQ, Hoag GE, Dahmani A, Block PA (2005) Degradation of volatile organic compounds with thermally activated persulfate oxidation. Chemosphere 61:551-560

Hunkeler D, Aravena R, Parker BL, Cherry JA, Diao X (2003) Monitoring oxidation of chlorinated ethenes by permanganate in groundwater using stable isotopes: laboratory and field studies. Environ Sci Technol 37:798-804

ITRC (2005) Technical and regulatory guidance for in situ chemical oxidation of contaminated soil and groundwater. Interstate Technology and Regulatory Council, In Situ Chemical Oxidation Team, Washington

Jones A, Escobar M, Serlin C, Sercu B, Holden P, Stollar R, Murphy P (2009) Microbial community composition assessment during in situ chemical oxidation with permanganate. In: Proceedings of the tenth international in situ and on-site bioremediation symposium. Battelle, Baltimore, pp K-14

Jung H, Ahn Y, Choi H, Kim IS (2005) Effects of in-situ ozonation on indigenous microorganisms in diesel contaminated soil: survival and regrowth. Chemosphere 61:923-932

Kao CM, Wu MJ (2000) Enhanced TCDD degradation by Fenton's reagent preoxidation. J Hazard Mater 74:197-211

Koch SA, Rice JM, Stolzenburg TR, Baker K, Haselow J (2007) Reversing full-scale ISCO. In: Proceedings of the ninth international in situ and on-site bioremediation symposium. Battelle, Baltimore, pp G-06

Krumins V, Park JW, Son EK, Rodenburg LA, Kerkhof LJ, Haggblom MM, Fennell DE (2009) PCB dechlorination enhancement in Anacostia River sediment microcosms. Water Res 43:4549-4558

Kubal M, Janda V, Benes P, Hendrych J (2008) In situ chemical oxidation and its application to remediation of contaminated soil and groundwater. Chem Listy 102:493-499 
Kulik N, Goi A, Trapido M, Tuhkanen T (2006) Degradation of polycyclic aromatic hydrocarbons by combined chemical pre-oxidation and bioremediation in creosote contaminated soil. J Environ Manage 78:382-391

Ladaa T, Tingle A, Mayer R, McInturff B, Jerrard C, Hodges J, Morrissey D (2008) Phased full-scale remediation of a complex site using a treatment train of multiple technologies. In: Proceedings of the sixth international conference on remediation of chlorinated and recalcitrant compounds. Battelle, Monterey, pp D-002

Lee B, Hosomi M (2001) A hybrid Fenton oxidation-microbial treatment for soil highly contaminated with benz(a)anthracene. Chemosphere 43:1127-1132

Lee BT, Kim KW (2002) Ozonation of diesel fuel in unsaturated porous media. Appl Geochem 17:1165-1170

Lee PKH, Macbeth TW, Sorenson KS, Deeb RA, Alvarez-Cohen L (2008) Quantifying genes and transcripts to assess the in situ physiology of "Dehalococcoides" spp. in a trichloroethene-contaminated groundwater site. Appl Environ Microbiol 74:2728-2739

Lessard L, Head M, Glod C (2007) Gasoline and fuel oil remediation using biologically enhanced chemical oxidation. In: Proceedings of the ninth international in situ and on-site bioremediation symposium. Battelle, Baltimore, pp H-18

Liang YT, Van Nostrand JD, Wang J, Zhang X, Zhou JZ, Li GH (2009) Microarray-based functional gene analysis of soil microbial communities during ozonation and biodegradation of crude oil. Chemosphere 75:193-199

Luhrs RC, Lewis RW, Huling SG (2006) ISCO's long-term impact on aquifer conditions and microbial activity. In: Proceedings of the fifth international conference on remediation of chlorinated and recalcitrant compounds. Battelle, Monterey, pp D-48

Macbeth T, Peterson L, Starr R, Sorenson Jr K, Goehlert R, Moor K (2005) ISCO impacts on indigenous microbes in a PCE-DNAPL contaminated aquifer. In: Proceedings of the eighth international in situ and on-site bioremediation symposium. Battelle, Baltimore, pp D-22

Macbeth TW, Goehlert R, Moor K (2007) Effect of iterative permanganate injections on indigenous microbes in a PCEDNAPL contaminated aquifer. In: Proceedings of the ninth international in situ and on-site bioremediation symposium. Battelle, Baltimore, pp G-03

MacKinnon LK, Thomson NR (2002) Laboratory-scale in situ chemical oxidation of a perchloroethylene pool using permanganate. J Contam Hydrol 56:49-74

Major DW, McMaster ML, Cox EE, Edwards EA, Dworatzek SM, Hendrickson ER, Starr MG, Payne JA, Buonamici LW (2002) Field demonstration of successful bioaugmentation to achieve dechlorination of tetrachloroethene to ethene. Environ Sci Technol 36:5106-5116

Malina G, Grotenhuis JTC (2000) The role of biodegradation during bioventing of soil contaminated with jet fuel. Appl Biochem Biotechnol 88:59-76

Marley MC, Parikh JM, Droste EX, Lee AM, Dinardo PM, Woody BA, Hoag GE, Chheda PV (2003) Enhanced reductive dechlorination resulting from a chemical oxidation pilot test, In situ and on-site bioremediation-2003. In: Proceedings of the Seventh International In Situ and On-Site Bioremediation Symposium. Battelle, Orlando, p A17

Masten SJ, Davies SHR (1997) Efficacy of in-situ ozonation for the remediation of PAH contaminated soils. J Contam Hydrol 28:327-335

Menendez-Vega D, Gallego JLR, Pelaez AI, de Cordoba GF, Moreno J, Munoz D, Sanchez J (2007) Engineered in situ bioremediation of soil and groundwater polluted with weathered hydrocarbons. Eur J Soil Biol 43:310-321

Miller CM, Valentine RL, Roehl ME, Alvarez PJJ (1996) Chemical and microbiological assessment of pendimethalin-contaminated soil after treatment with Fenton's reagent. Water Res 30:2579-2586
Nam K, Rodriguez W, Kukor JJ (2001) Enhanced degradation of polycyclic aromatic hydrocarbons by biodegradation combined with a modified Fenton reaction. Chemosphere 45:11-20

Ndjou'ou AC, Bou-Nasr J, Cassidy D (2006) Effect of Fenton reagent dose on coexisting chemical and microbial oxidation in soil. Environ Sci Technol 40:2778-2783

Northup A, Cassidy D (2008) Calcium peroxide (CaO2)for use in modified Fenton chemistry. J Hazard Mater 152:1164-1170

Ochs D, Singh IP (2007) Alkaline peroxidation treatment field applications for BTEX and MTBE treatment. In: Proceedings of the ninth international in situ and on-site bioremediation symposium. Battelle, Baltimore, pp C-49

Ormad P, Puig A, Sarasa J, Roche P, Martin A, Ovelleiro JL (1994) Ozonation of waste-water resulting from the production of organochlorine plaguides derived from DDT and trichlorobenzene. Ozone Sci Eng 16:487-503

Palmroth MRT, Langwaldt JH, Aunola TA, Goi A, Munster U, Puhakka JA, Tuhkanen TA (2006a) Effect of modified Fenton's reaction on microbial activity and removal of PAHs in creosote oil contaminated soil. Biodegradation 17:131-141

Palmroth MRT, Langwaldt JH, Aunola TA, Goi A, Puhakka JA, Tuhkanen TA (2006b) Treatment of PAH-contaminated soil by combination of Fenton's reaction and biodegradation. J Chem Technol Biotechnol 81:598-607

$\mathrm{Pu}$ XC, Cutright TJ (2007) Degradation of pentachlorophenol by pure and mixed cultures in two different soils. Environ Sci Pollut Res $14: 244-250$

Rivas FJ (2006) Polycyclic aromatic hydrocarbons sorbed on soils: a short review of chemical oxidation based treatments. J Hazard Mater 138:234-251

Sahl J, Munakata-Marr J (2006) The effects of in situ chemical oxidation on microbiological processes: a review. Remed J 16:57-70

Sahl JW, Munakata-Marr J, Crimi ML, Siegrist RL (2007) Coupling permanganate oxidation with microbial dechlorination. Water Environ Res 79:5-12

Salanitro JP, Johnson PC, Spinnler GE, Maner PM, Wisniewski HL, Bruce C (2000) Field scale demonstration of enhanced MTBE bioremediation through aquifer bioaugmentation and oxygenation. Environ Sci Technol 34:4152-4162

Scheutz C, Durant ND, Dennis P, Hansen MH, Jorgensen T, Jakobsen R, Cox EE, Bjerg PL (2008) Concurrent ethene generation and growth of dehalococcoides containing vinyl chloride reductive dehalogenase genes during an enhanced reductive dechlorination field demonstration. Environ Sci Technol 42:9302-9309

Schnarr M, Truax C, Farquhar G, Hood E, Gonullu T, Stickney B (1998) Laboratory and controlled field experiments using potassium permanganate to remediate trichloroethylene and perchloroethylene DNAPLs in porous media. J Contam Hydrol 29:205-224

Semple KT, Morriss AWJ, Paton GI (2003) Bioavailability of hydrophobic organic contaminants in soils: fundamental concepts and techniques for analysis. Eur J Soil Sci 54:809-818

Seol Y, Zhang H, Schwartz FW (2003) A review of in situ chemical oxidation and heterogeneity. Environ Eng Geosci 9:37-49

Siegrist RL, Lowe KS, Murdoch LC, Case TL, Pickering DA (1999) In situ oxidation by fracture emplaced reactive solids. J Environ Eng 125:429-440

Siegrist RL, Urynowicz MA, Crimi ML, Lowe KS (2002) Genesis and effects of particles produced during in situ chemical oxidation using permanganate. J Environ Eng 128:1068-1079

Singh A (2009) Biological remediation of soil: an overview of global market and available technologies. In: Singh A, Ward OP (eds) Advances in applied bioremediation. Soil biology. Springer, Berlin, pp 1-19

Sirguey C, Silva P, Schwartz C, Simonnot MO (2008) Impact of chemical oxidation on soil quality. Chemosphere 72:282-289 
Smith AE, Hristova K, Wood I, Mackay DM, Lory E, Lorenzana D, Scow KM (2005) Comparison of biostimulation versus bioaugmentation with bacterial strain PM1 for treatment of groundwater contaminated with methyl tertiary butyl ether (MTBE). Environ Health Perspect 113:317-322

Song DL, Conrad ME, Sorenson KS, Alvarez-Cohen L (2002) Stable carbon isotope fractionation during enhanced in situ bioremediation of trichloroethene. Environ Sci Technol 36:2262-2268

Straube WL, Nestler CC, Hansen LD, Ringleberg D, Pritchard PH, Jones-Meehan J (2003) Remediation of polyaromatic hydrocarbons (PAHs) through landfarming with biostimulation and bioaugmentation. Acta Biotechnol 23:179-196

Studer J, Davis G, Baldwin B, Cronk G (2009) Impact of in situ chemical oxidation on native biological populations - review of case studies. In: Proceedings of the tenth international in situ and on-site bioremediation symposium. Battelle, Baltimore, pp K-13

Surridge A, Wehner F, Cloete T (2009) Bioremediation of polluted soil. In: Singh A, Ward OP, Kuhad RC (eds) Advances in applied bioremediation. Soil biology. Springer, Berlin, pp 103-121

Tas N, MHAv E, WMd V, Smidt H (2009) The little bacteria that can-diversity, genomics and ecophysiology of 'Dehalococcoides' spp. in contaminated environments. Microb Biotechnol 3:389-402

Teel AL, Cutler LM, Watts RJ (2009) Effect of sorption on contaminant oxidation in activated persulfate systems. J Environ Sci Health A Tox Hazard Subst Environ Eng 44:1098-1103

Tsai T, Kao C, Yeh T, Lee M (2008) Chemical oxidation of chlorinated solvents in contaminated groundwater: review. Pract Period Hazard Toxic Radioact Waste Manag 12:116-126

Tsai TT, Kao CM, Surampalli RY, Chien HY (2009a) Enhanced bioremediation of fuel-oil contaminated soils: laboratory feasibility study. J Environ Eng 135:845-853

Tsai TT, Kao CM, Yeh TY, Liang SH, Chien HY (2009b) Remediation of fuel oil-contaminated soils by a three-stage treatment system. Environ Eng Sci 26:651-659

Tsai TT, Kao CM, Yeh TY, Liang SH, Chien HY (2009c) Application of surfactant enhanced permanganate oxidation and bidegradation of trichloroethylene in groundwater. J Hazard Mater 161:111-119

Tsitonaki A, Petri B, Crimi M, Mosbaek H, Siegrist RL, Bjerg PL (2010) In situ chemical oxidation of contaminated soil and groundwater using persulfate: a review. Crit Rev Environ Sci Technol 40:55-91
Valderrama C, Alessandri R, Aunola T, Cortina JL, Gamisans X, Tuhkanen T (2009) Oxidation by Fenton's reagent combined with biological treatment applied to a creosote-comtaminated soil. J Hazard Mater 166:594-602

Vella P, Veronda B (1993) Oxidation of trichloroethylene: a comparison of potassium permanganate and Fenton's reagent. In: 3rd international symposium, chemical oxidation: technology for the nineties. Vanderbilt University, Nashville, pp 17-19

Volkering F, Quist JJ, van Velsen AFM, Thomassen PHG, Olijve M (1998) A rapid method for predicting the residual concentration after biological treatment of oil-polluted soil, ConSoil. Thomas Telford, Edinburgh, pp 251-259

Waddell J, Mayer G (2003) Effects of Fenton's reagent and potassium permanganate application on indigenous subsurface microbiota: a literature review. In: Proceedings of the 2003 Georgia Water Resources Conference. University of Georgia, Athens, pp 23-24

Watts RJ, Teel AL (2005) Chemistry of modified Fenton's reagent (catalyzed $\mathrm{H} 2 \mathrm{O} 2$ propagations-CHP) for in situ soil and groundwater remediation. J Environ Eng 131:612-622

Watts RJ, Udell MD, Rauch PA, Leung SW (1990) Treatment of pentachlorophenol-contaminated soils using Fentons reagent. Hazard Waste Hazard Mater 7:335-345

Watts RJ, Stanton PC, Howsawkeng J, Teel AL (2002) Mineralization of a sorbed polycyclic aromatic hydrocarbon in two soils using catalyzed hydrogen peroxide. Water Res 36:4283-4292

Westersund J, Fernandes L, Jones S, Clought H (2006) Stimulating anaerobic reductive dechlorination following chemical oxidation treatment. In: Proceedings of the fifth international conference on remediation of chlorinated and recalcitrant compounds. Battelle, Monterey, pp D-56

Wiberg KB, Saegebarth KA (1957) The mechanisms of permanganate oxidation. IV. Hydroxylation of olefins and related reactions. J Am Chem Soc 79:2822-2824

Wrenn BA, Ma X, King T, Lee K, Venosa AD (2007) Effect of potassium permanganate on the biodegradation of weathered crude oil from Indiana Harbor Canal. In: Proceedings of the ninth international in situ and on-site bioremediation symposium. Battelle, Baltimore, pp C-55

Xie GB, Barcelona MJ (2003) Sequential chemical oxidation and aerobic biodegradation of equivalent carbon number-based hydrocarbon fractions in jet fuel. Environ Sci Technol 37:4751-4760 